\title{
PENGARUH EKSTRAK BIJI ANGGUR MERAH (Vitis vinifera) TERHADAP PENURUNAN KADAR GLUKOSA DARAH TIKUS PUTIH STRAIN WISTAR MODEL DIABETIKUM
}

\author{
Madona Clara Yosinta Djoka ${ }^{1}$, Meddy Setiawan ${ }^{2}$, Anisa Hasanah ${ }^{3}$ \\ Fakultas Kedokteran Universitas Muhammadiyah Malang, J1. Bendungan Sutami No. 188A, Kota Malang, \\ 65145, Indonesia, (0341)551149
}

\begin{abstract}
ABSTRAK
Pengaruh Ekstrak Biji Anggur Merah (Vitis vinifera) terhadap Penurunan Kadar Glukosa Darah Tikus Putih Strain Wistar Model Diabetikum. Latar Belakang : Prevalensi diabetes di Indonesia mengalami peningkatan yang nyata. Saat ini berkembang pengobatan fitofarmaka salah satunya adalah biji anggur merah. Biji anggur merah mengandung Oligomer Proanthocyanidin Complex (OPC), Flavonoid, dan Catechin yang mampu menurunkan kadar glukosa darah pada penderita diabetes. Tujuan : Membuktikan pengaruh ekstrak biji anggur merah (Vitis vinifera) terhadap penurunan kadar glukosa darah tikus putih strain wistar model diabetikum. Metode : True experimental, dengan rancangan The pre post test Control Group Design. Sampel tikus putih strain wistar yang dibagi 3 kelompok. I: kontrol positif hanya injeksi Alloxan, II: diberi Alloxan dan ekstrak biji anggur merah (Vitis vinifera) 0,093 gr/200 gr BB/hari, dan III: diberi Alloxan dan ekstrak biji anggur merah (Vitis vinifera) 0,187 gr/200 gr BB/hari. Analisis data menggunakan One way Anova, uji tukey 1\%, uji korelasi, dan uji regresi linier. Hasil Penelitian dan Diskusi : Dari hasil uji One way Anova, didapatkan pengaruh yang bermakna (nilai sig $=0,000<\alpha(0,01)$ ) antar kelompok perlakuan. Hasil uji tukey $1 \%$, pada kelompok I, II dan III didapatkan notasi yang berbeda dari tiap-tiap kelompok yang artinya tiap-tiap kelompok mempunyai kadar glukosa darah yang berbeda satu sama lain. Hasil uji korelasi didapatkan nilai pearson correlation $=-0,902$ pada glukosa darah puasa dan $-0,962$ pada glukosa darah 2 jam post pandrial. Hasil uji regresi didapatkan $\mathrm{R}^{2}=0,814$ pada glukosa darah puasa dan $\mathrm{R}^{2}=$ 0,925 pada glukosa darah 2 jam post pandrial. Kesimpulan : Pemberian ekstrak biji anggur merah (Vitis vinifera) berpengaruh terhadap penurunan kadar glukosa darah.
\end{abstract}

\begin{abstract}
The Effect of Red Grape Seed Extract (Vitis vinifera) to Decrease the Blood Glucose Level of White Rats Strain Wistar Model of Diabetic. Background: The prevalence of diabetes in Indonesia had noticeable increase. Nowadays, the treatment of phytopharmaca had been developed, one of them is red grape seed. It contains Oligomer Proanthocyanidin Complex (OPC), Flavonoid, and Catechin that are able to decrease the blood glucose level in diabetic patients. Objective : The aim of the study is to prove The Effect of Red Grape Seed Extract (Vitis vinifera) to decrease the blood glucose level of white rats strain wistar model of diabetic. Method: True experiment with The Pre Post Control Group Design. The strain wistar samples were divided into 3 groups. Group I: positive control with Alloxan injection, group II : Injected with Alloxan and 0,093 gr/200 gr BB/day red grape seed extract. And group III: Injected with Alloxan and 0,187 gr/200 gr BB/day red grape seed extract. Data were analyzed by One way Anova, 1\% tukey test, correlation test, and linier regression test. Result and Discussion: One way Anova test showed significant effect (sigvalue $=0,000<\alpha(0,01)$ ) on the control and experiment groups. From Tukey test 1\% result showed there was different notation from each groups which meant each group has the differences at blood glucose level. Correlation test showed pearson correlation = -0,902 fasting glucose blood and -0,962 2 hours post pandrial. Regression test showed $\mathrm{R} 2=0,814$ fasting glucose blood and $\mathrm{R} 2=0,9252$ bours post pandrial. Conclusion: The delivered of red grape seed extract (Vitis vinifera) take effects to decrease the blood glucose level.
\end{abstract}

Key words : red grape seed extract (Vitis vinifera), antioxidant, blood glucose, white rats strain wistar, Alloxan.

\section{PENDAHULUAN}

Diabetes merupakan salah satu ancaman utama bagi kesehatan umat manusia pada abad 21. Perserikatan Bangsa-bangsa membuat perkiraan bahwa pada tahun 2000 jumlah pengidap diabetes di atas umur 20 tahun berjumlah 150 juta orang dan dalam kurun waktu 25 tahun kemudian, pada tahun 2025, jumlah itu akan membengkak menjadi 300 juta orang. Menurut penelitian epidemiologi yang sampai saat ini dilaksanakan di Indonesia, dalam jangka waktu 30 tahun (1990-2020) penduduk Indonesia akan naik sebesar $40 \%$ dengan peningkatan jumlah pasien diabetes yang jauh lebih besar yaitu 86-138\% (Suyono, 2009). Dari tahun ke tahun, jumlah pengidap diabetes dapat meningkat pesat seiring bertambahnya kemakmuran suatu populasi. Diabetes dapat menye babkan komplikasi jangka panjang yang melibatkan mata, ginjal, syaraf dan pembuluh darah sehingga mortalitasnya sangat tinggi (Isselbacher, 2000). 
Ekstrak biji anggur dapat digunakan untuk pengobatan diabetes (Chris, 2009). Pada penelitian yang dilakukan oleh Hassan, 2010 dijelaskan bahwa ekstrak dari biji anggur merah adalah penangkap reactive oxygen spesies (ROS) yang baik. Hasil penelitian ini adalah ekstrak biji anggur merah merupakan sumber potensial dari antioksidan alami yang dapat digunakan sebagai fitofarmaka. Seiring dengan meningkatnya angka kejadian penderita Diabetes Melitus, maka penelitian ini bertujuan untuk membuktikan bagaimana pengaruh ekstrak biji anggur merah terhadap penurunan kadar glukosa darah tikus strain wistar model diabetikum.

Tujuan Umum Penelitian Membuktikan pengaruh ekstrak biji anggur merah (Vitis vinifera) terhadap penurunan kadar glukosa darah tikus putih strain wistar model diabetikum. Tujuan khusus penelitian ini adalah untuk mengetahui pengaruh ekstrak biji anggur merah (Vitis vinifera) terhadap penurunan glukosa darah puasa dan 2 jam post pandrial tikus putih strain wistar model diabetikum. tujuan kedua untuk mengetahui dosis ekstrak biji anggur merah (Vitis vinifera) yang paling efektif dalam menurunkan kadar glukosa darah tikus putih strain wistar model diabetikum. Manfaat Penelitian dalam bidang akademis adalah menambah wawasan dalam ilmu pengetahuan kedokteran. Selain itu, sebagai dasar untuk melakukan penelitian selanjutnya yang berkaitan dengan pengaruh ekstrak biji anggur merah terhadap penyakit degeneratif lainnya. Manfaat Klinis penelitian sebagai alternatif untuk menurunkan kadar gula darah pada penderita diabetes melitus. Manfaat bagi masyarakat untuk memberi informasi kepada masyarakat tentang pengaruh ekstrak biji anggur merah (Vitis vinifera) terhadap penurunan kadar glukosa darah tikus strain wistar model diabetikum.

\section{METODE PENELITIAN}

Penelitian ini merupakan penelitian true eksperimental dengan menggunakan metode ThePre- Post Test Control Group Design. Penelitian ini akan dilaksanakan selama 1 bulan bertempat di Laboratorium Biokimia Universitas Muhammadiyah Malang. Populasi penelitian adalah tikus putih (Rattus novergicus) strain wistar dewasa, jenis kelamin jantan, umur 2-3 bulan, berat badan 150-250 gram dengan kondisi sehat yang ditandai dengan gerakannya yang aktif. (Ghoshal, 1978). Sampel diambil secara random dari populasi tikus putih (Rattus norwegicus) strain wistar jantan sebagai hewan coba. Sampel terdiri atas 3 kelompok. Besar sampel dalam penelitian ini menggunakan 24 ekor tikus, dibagi menjadi 3 kelompok dan masing-masing kelompok terdiri dari 9 ekor tikus yaitu klompok I : Kontrol positif (alloxan dan ekstrak biji anggur merah (Vitis vinifera)).Kelompok II : Pemberian alloxan dan ekstrak biji anggur merah (Vitis vinifera) 0,093 gr/200 gr BB/hari. Kelompok III : Pemberian alloxan dan ekstrak biji anggur merah (Vitis vinifera) 0,187 gr/200 gr $\mathrm{BB} /$ hari.

Karakteristik Sampel Penelitian ini menggunakan kriteria inklusi dan eksklusi. kriteria Inklusi yaitu umur 23 bulan. berat badan 150 - 250 gram (Sudjari, 1996). Jantan, strain wistar (Nicholas,1971). Sehat, ditandai dengan gerakan yang aktif. (Sudjari,1996). Kriteria Ekslusi yang dimaksud adalah tikus mati saat perlakuan, tikus tidak mau makan.

Definisi Ekstraksi biji anggur merah (Vitis vinifera) pada penelitian ini dilakukan secara maserasi kinetik dengan menggunakan pelarut etanol $80 \%$ sehingga diperoleh ekstrak etanol biji anggur (Vitis vinifera L. ) varietas merah. Alloxan adalah suatu senyawa yang sering digunakan untuk meningkatkan kadar glukosa darah pada tikus putih strain wistar dengan dosis $0,2 \mathrm{ml}$ (Studiawan dan santosa, 2005). Kadar Glukosa Darah yerdiri dari beberapa bagian. Kadar glukosa darah puasa normal pada tikus adalah $<85 \mathrm{mg} / \mathrm{dl}$. Kadar glukosa darah 2 jam post pandrial normal pada tikus adalah $<150 \mathrm{mg} / \mathrm{dl}$. Hiperglikemia adalah keadaan saat kadar glukosa darah tikus diatas normal $(>150 \mathrm{mg} / \mathrm{dl}$ ). Tikus putih strain wistar adalah hewan coba yang dipakai dalam penelitian ini adalah tikus putih (Rattus novergicus) strain wistar dewasa, jenis kelamin jantan, umur 2-3 bulan, berat badan 150-250 gram yang diambil secara random dari populasi tikus putih (Rattus norwegicus) strain wistar jantan sebagai hewan coba. Alat dan Bahan yang digunakan pada penelitian ini adalah sebagai berikut. Alat berupa timbangan untuk menimbang berat badan tikus, alat pemeliharaan tikus (Bak tikus, penutup kandang dari anyaman kawat, botol air, sekam, gelas ukur, alat untuk pengukuran gula darah tikus dengan metode GOD-PAP, botol ekstrak biji anggur merah, sonde modifikasi). Bahan yang digunakan adalah hewan percobaan, makanan tikus, zat yang diberikan untuk membuat tikus diabet Alloxan, biji Anggur Merah, $\mathrm{NaCl}$ 0,9\%, reagen, serum darah tikus.

Prosedur Penelitian meliputi beberapa proses. Pertama, adaptasi hewan percobaan. Tikus diaklimatisasi dahulu dengan lingkungan dan pakan selama satu minggu di laboratorium sebelum injeksi alloxan sambil diamati kesehatannya. Memberi makanan pada tikus 2 kali sehari. Makanan tikus adalah BRI, sedangkan untuk minum tikus diberikan aquades. Kedua, penentuan dosis Aquades. Aquades yang diberikan pada setiap kelompok adalah $2 \mathrm{ml} / 200$ gram BB. Dosis Alloxan, larutan alloxan diberikan pada seluruh tikus dengan dosis tunggal $0,2 \mathrm{ml}$ subkutan. Hal ini berdasarkan hasil uji pendahuluan dan penelitian sebelumnya oleh Studiawan dan Santosa (2005). Dosis Esktrak Biji Anggur Merah. Pada manusia, dosis ekstrak biji anggur merah efektif bila diberikan $5210 \mathrm{mg}-10440$ mg (Kemper, 1999). Berdasarkan penelitian yang dilakukan oleh Beecher, 2004 dijelaskan bahwa dalam 100 gr ekstrak biji anggur merah terdapat $2872 \mathrm{mg}$ proantocyanidin. Dari data dosis tersebut kemudian dikonversikan ke dalam dosis tikus. Konversi dapat dilihat pada tabel berikut (Laurence \& Bacharach, 1964). Pembuatan Ekstrak Biji Anggur Merah dilakukan sebagai berikut. Buah anggur merah (Vitis vinifera) dipisahkan dari bijinya. Kemudian bijinya dibersihkan dari sisa daging buah yang masih melekat. Kemudian biji buah anggur merah dikeringkan (di tempat teduh, suhu udara 25-30 C) selama satu minggu dan digiling menjadi bubuk halus. Bubuk biji anggur $(0,2 \mathrm{~g})$ dimaserasi dalam $20 \mathrm{ml}$ etanol $80 \%$ suling selama 24 jam pada suhu $5 \mathrm{C}$ dan sekurang-kurangnya 3 kali ekstraksi, sampai filtrat yang dihasilkan bening Filtrat yang didapat 
dipekatkan dengan menggunakan rotary evaporator selama \pm 1 jam dan dilanjutkan dengan menggunakan waterbath pada suhu $60 \mathrm{oC}$ yang dijaga konstan sampai didapatkan bobot konstan, sehingga diperoleh biji anggur ekstrak etanol. (Hassan, 2010). Pengambilan darah tikus pada hari ke8 diambil melalui ekor sebanyak $0,2 \mathrm{cc}$, setelah hari ke-28 diambil melalui ekor tikus. Darahnya diteteskan pada strip glukosa dan ditentukan angka glukosa darahnya dengan melihat hasilnya pada glukometer.

Pada tahap percobaan, pembuatan tikus diabet adalah pada uji pendahuluan dilakukan upaya peningkatan kadar glukosa darah tikus dengan menginduksi alloxan. Kemudian, kadar glukosa tikus dikontrol pada hari ke-7 untuk meyakinkan bahwa alloxan dengan dosis tersebut menyebabkan kondisi diabetik. Dua puluh empat ekor tikus kemudian dibagi dalam 4 kelompok secara random, masingmasing sebanyak 6 ekor. Kelompok I tidak diberi pemberian alloxan karena kelompok I adalah kelompok kontrol negatif. Sedangkan untuk kelompok II,III dan IV diberi perlakuan pemberian injeksi larutan alloxan tetrahidrat dengan dosis tunggal $0,2 \mathrm{ml}$ secara subkutan setiap hari $1 \mathrm{x} /$ hari, selama 1 minggu untuk mendapatkan tikus diabet. Pemberian ekstrak biji anggur merah adalah kelompok I sebagai kelompok kontrol positif hanya diberi perlakuan injeksi alloxan, sedangkan pada kelompok II dan III selain pemberian injeksi larutan alloxan pada hari ke 8 selama 1 minggu juga diberi perlakuan Ekstrak Biji Anggur Merah. Ekstrak Biji Anggur Merah diberikan masing-masing dengan dosis 0,093 gr/200 gr BB/hari dan 0,187 gr/200 gr BB/hari tikus/hari. Untuk keseragaman maka pemberian Ekstrak Biji Anggur Merah dilakukan setiap hari selama 28 hari jam 12.00 - 13.00 WIB siang. Dalam penelitian ini, pemeriksaan kadar gula darah pada tikus dilakukan 2 jam setelah makan (post pandrial). Menurut Kusumawati (2004), kadar glukosa darah tikus dalam kondisi normal adalah 50-135 mg/dl. Pemeriksaan kadar glukosa pada tikus dilakukan pada hari ke-1, ke-14, dan ke-28. Pemeriksaan pada hari ke-14 bertujuan untuk mengetahui efek hiperglikemik dari alloxan. Sedangkan pada hari ke-28 bertujuan untuk mengetahui efek pemberian ekstrak biji anggur merah, yang merupakan akhir dari perlakuan terhadap hewan coba. Pengukuran kadar glukosa dalam penelitian ini menggunakan metode enzimatik GOD-PAP sebagai berikut : Glukosa dapat ditentukan dengan enzimatik dengan penambahan enzim glukosa oksidase (GOD) dan peroksidase (POD). Dengan adanya oksigen atau udara, glukosa dioksidasi oleh enzim GOD menjadi asam glukonat disertai pembentukan $\mathrm{H} 2 \mathrm{O} 2$. Dengan adanya enzim POD, H2O2 akan membebaskan oksigen yang akan mengoksidasi akseptor kromogen yang sesuai serta memberikan warna yang sesuai pula. Akseptor kromogen yang dimaksud adalah 4aminofenazon, dapat pula digunakan o-dianisidin, dan NNdimetil anilin. Kadar glukosa darah ditentukan berdasarkan intensitas warna yang terjadi dan diukur dengan spektrofotometri. Metode ini spesifik untuk glukosa saja karena enzim GOD akan mengkatalisa reaksi oksidasi glukosa menjadi asam glukonat dan peroksidase (Thomas, 1998).

Analisis statistik yang digunakan adalah One way ANOVA, yaitu untuk menguji hipotesis kesamaan rata-rata antar kelompok ( $>2$ kelompok), apakah rata-rata antar sampel berbeda secara signifikan atau tidak; dengan tingkat kepercayaan $\alpha=0,01$, di mana apabila diperoleh $\alpha>0,01$ artinya tidak ada perbedaan yang bermakna sebaliknya bila $\alpha<0,01$ menunjukkan adanya perbedaan yang bermakna. Uji Tukey 1\% merupakan uji kelanjutan dari uji ANOVA, digunakan untuk mengetahui perbedaan yang bermakna antar tiap kelompok perlakuan dalam penelitian. Uji korelasi digunakan untuk mengetahui hubungan yang signifikan antara dosis ekstrak biji anggur merah (Vitis vinifera) dengan perlakuan (penurunan kadar gula darah). Uji Regresi untuk mengetahui ada tidaknya hubungan dosis ekstrak biji anggur merah (Vitis vinifera) dengan perlakuan (penurunan kadar gula darah) dan mengetahui seberapa kuat hubungan tersebut.

\section{HASIL DAN PEMBAHASAN}

Gaya hidup kembali ke alam (back to nature), merupakan gaya hidup yang semakin digemari banyak orang (Furnawanthi, 2002). Dalam bidang medis, salah satu yang terpenting adalah mulai berkembangnya cara pengobatan dengan bahan alam yang lebih dikenal dengan fitofarmaka sebagai alternatif lain dari pengobatan kimiawi (Kumalaningsih, 2007). Hal ini terjadi karena semakin banyaknya ditemukan berbagai fakta baru bahwa tidak sedikit dari bahan-bahan yang diteliti dan telah di konsumsi secara umum dari penemuan- penemuan terdahulu, memberikan manfaat pada kehidupan manusia khususnya di bidang kesehatan (Rohdiana, 2009). Indonesia merupakan negara yang kaya akan keanekaragaman hayati. Salah satunya adalah tanaman anggur. Ada beberapa jenis dari anggur antara lain anggur hijau, merah, dan hitam (Wiriyanta, 2008). Anggur varietas merah merupakan varietas yang sudah dikenal sebagai varietas unggul, karena anggur ini cocok dengan kondisi alam Indonesia (Rukmana, 1998). Pada umumnya, buah anggur tumbuh di daerah tropis dengan ketinggian antara 5-1000 m diatas permukaan laut. Suhu cuaca antara 250C-300C dengan curah hujan yang diperlukan oleh tanaman ini sekitar $800 \mathrm{~mm}$ per tahun (Wiriyanta, 2008).

Anggur (Vitis vinifera) adalah salah satu buah yang paling banyak dikonsumsi di seluruh dunia dan memiliki kepentingan besar sebagai obat serta gizi selama ribuan tahun (Arora, 2010). Pemanfaatan buah anggur seringkali hanya memanfaatkan daging buah sedangkan bijinya dibuang (Subehi, 2008). Biji anggur mengandung lemak, protein, karbohidrat, dan $5-8 \%$ polifenol tergantung dari varietas. Polifenol yang terdapat pada biji anggur terutama flavonoid yang meliputi asam galat, catechin, epicatechin, gallocatechin, epigallocatechin, dan procianidin yang tinggi. Biji anggur juga mengandung fenol berupa proanthocyanidins (Shi, 2003). Peneliti di Perancis telah menemukan suatu senyawa bioflavonoid yang tidak berwarna pada biji anggur merah yang ternyata mengandung proanthocyanidins sebanyak 95\%. Dalam penelitiannya, zat tersebut diberi nama Oligomer Proanthocyanidin Complex (OPC) (Liers, 1993). Penelitian menunjukkan bahwa antioksidan kuat dari OPC mempunyai potensi 50x lebih besar daripada vitamin $C$ dan 20x lebih besar daripada vitamin E (Shi, 2003). 
Penelitian terdahulu yang berasal dari penelitian Alawwadi dan rekan hanya menggambarkan aktivitas antidiabetes dari ekstrak polifenol anggur merah pada tikus yang diinduksi streptozotocin (STZ) (Al-awwadi, 2004). Kandungan yang terdapat pada biji anggur merah yang dapat digunakan untuk menurunkan glukosa darah adalah OPC, flavonoid dan catechin. OPC yang terdapat pada biji anggur berpengaruh besar terhadap aktifitas antioksidan dan proteksi DNA dari zat kimia (Bagchi, 1998). Antioksidan berperan dalam pengobatan diabetes melitus untuk memperbaiki sel $\beta$ pankreas yang rusak sehingga dapat meningkatkan sekresi insulin (Chauhan, 2008). Flavonoid dapat berperan sebagai antioksidan. Kemampuan Flavonoid sebagai antioksidan mampu mengurangi ROS. Hal ini dapat menimbulkan efek protektif terhadap sel beta pankreas dan meningkatkan sensitivitas insulin (Kaneto, 2009). Flavonoid memiliki mekanisme dalam penghambatan fosfodiesterase sehingga kadar Cyclic Adeno Monophosphat (cAMP) dalam sel beta pankreas meninggi. Hal ini akan merangsang sekresi insulin melalui jalur Ca (Ohno, 1993). Peningkatan kadar cAMP ini akan menyebabkan penutupan kanal $\mathrm{K}+\mathrm{ATP}$ dalam membran plasma sel beta. Keadaan ini mengakibatkan terjadinya depolarisasi membrane dan membukanya saluran $\mathrm{Ca}$ tergantung-voltasi sehingga mempercepat masuknya ion Ca ke dalam sel. Peningkatan ion Ca dalam sitoplasma sel beta ini akan menyebabkan sekresi insulin oleh sel beta pankreas (Sato, 1999). Senyawa Catechin menghambat penyerapan glukosa usus (Shimizu, 2000). Senyawa Catechin merupakan antioksidan, antikanker, antimutagenik, dan antidiabetes (Rohdiana, 2009).

Penelitian ini merupakan penelitian true experiment dengan Pre Post Test Control Group Design untuk membuktikan pengaruh ekstrak biji aggur merah (Vitis vinifera) terhadap penurunan glukosa darah tikus putih strain wistar model diabetikum. Glukosa darah yang diukur yaitu kadar glukosa darah puasa dan kadar glukosa darah 2 jam PP. Pada penelitian ini dilakukan tiga kali pengukuran kadar glukosa darah. Pengukuran pertama dilakukan pada awal perlakuan. Pengukuran kedua dilakukan setelah pemberian Alloxan dosis $0,2 \mathrm{ml} \mathrm{SC}$ yang diberikan pada kelompok I, II dan III selama 7 hari. Kemudian pengukuran ketiga dilakukan setelah pemberian ekstrak biji anggur merah yang diberikan pada kelompok II dan III dengan dosis $0,093 \mathrm{gr} / 200 \mathrm{gr} \mathrm{BB} /$ hari dan dosis $0,187 \mathrm{gr} /$ 200 gr BB/hari selama 28 hari. Dari hasil pengukuran tersebut dapat dilihat pada awal perlakuan rerata kadar glukosa darah puasa tikus putih strain wistar tertinggi terdapat pada kelompok 1 yaitu 73,631, sedangkan kadar glukosa darah 2 jam PP tikus putih strain wistar tertinggi terdapat pada kelompok 3 yaitu 118,595. Kadar glukosa darah puasa normal yaitu $<85 \mathrm{mg} / \mathrm{dl}$. Sedangkan untuk kadar glukosa darah 2 jam PP normal yaitu $<150 \mathrm{mg} / \mathrm{dl}$.

Dari hasil pengukuran tersebut dapat dilihat setelah pemberian Alloxan rerata kadar glukosa darah puasa tikus putih strain wistar tertinggi terdapat pada kelompok 2 yaitu 105,963, sedangkan kadar glukosa darah 2 jam PP tikus putih strain wistar tertinggi terdapat pada kelompok 2 yaitu 224,956. Terjadi peningkatan kadar glukosa darah puasa dari kadar normal yaitu $<85 \mathrm{mg} / \mathrm{dl}$ menjadi $>85 \mathrm{mg} / \mathrm{dl}$. Sedangkan untuk peningkatan kadar glukosa darah 2 jam
PP dari kadar normal yaitu $<150 \mathrm{mg} / \mathrm{dl}$ meningkat menjadi $>150 \mathrm{mg} / \mathrm{dl}$. Dari hasil pengukuran tersebut dapat dilihat setelah pemberian ekstrak biji anggur merah rerata kadar glukosa darah puasa tikus putih strain wistar terendah terdapat pada kelompok 3 dengan pemberian dosis ekstrak biji anggur merah $0,093 \mathrm{gr} / 200 \mathrm{gr} \mathrm{BB} / \mathrm{hari}$ yaitu 65.724 , sedangkan kadar glukosa darah 2 jam PP tikus putih strain wistar terendah terdapat pada kelompok 3 dengan pemberian dosis ekstrak biji anggur merah 0,093 gr/ 200 gr BB/hari yaitu 149.558 .

Tabel uji One way ANOVA menunjukkan rata-rata antar sampel berbeda secara signifikan atau tidak; dengan tingkat kepercayaan $\alpha=0,01$, di mana apabila diperoleh $\alpha>$ 0,01 artinya tidak ada perbedaan bermakna sebaliknya bila $\alpha$ $<0,01$ menunjukkan adanya perbedaan bermakna. Uji menunjukkan bahwa nilai sig $=0,000$ lebih kecil daripada $\alpha$ $=0,01$ yang berarti terdapat perbedaan bermakna antara pemberian ekstrak biji anggur merah (Vitis vinifera) terhadap kadar glukosa darah puasa tikus putih strain wistar setelah pemberian ekstrak biji anggur merah (Vitis vinifera). Uji menunjukkan bahwa nilai sig $=0,000$ lebih kecil daripada $\alpha$ $=0,01$ yang berarti terdapat perbedaan bermakna antara pemberian ekstrak biji anggur merah (Vitis vinifera) terhadap penurunan kadar glukosa darah 2 jam PP tikus putih strain wistar setelah pemberian Ekstrak Biji Anggur Merah (Vitis vinifera). Uji Tukey $1 \%$ untuk mengetahui perbedaan yang bermakna pada masing- masing kelompok dan bagaimana perbedaan tersebut. Berdasarkan perhitungan di atas maka dapat dikatakan bahwa terdapat perbedaan yang bermakna antar kelompok perlakuan.

Uji korelasi digunakan untuk mengetahui hubungan yang signifikan antara dosis ekstrak biji anggur merah (Vitis vinifera) dengan penurunan kadar glukosa darah. Nilai sig (2-tailed) $=0,000<\alpha(0,01)$, hal tersebut menunjukkan korelasi yang berbanding terbalik bermakna yang berarti bahwa semakin tinggi dosis ekstrak biji anggur merah menyebabkan semakin besar penurunan glukosa darah puasa tikus putih strain wistar diabetes pada akhir perlakuan. $\mathrm{Hal}$ ini ditunjukkan dengan nilai pearson correlation $=-0,902$. Nilai sig $(2$-tailed $)=0,000<\alpha(0,01)$, hal tersebut menunjukkan korelasi yang berbanding terbalik bermakna yang berarti bahwa semakin tinggi dosis ekstrak biji anggur merah menyebabkan semakin besar penurunan glukosa darah 2 jam pp tikus putih strain wistar diabetes pada akhir perlakuan. Hal ini ditunjukkan dengan nilai pearson correlation $=-0,962$.

Uji regresi digunakan untuk menentukan hubungan antara dosis ekstrak biji anggur merah (Vitis vinifera) terhadap penurunan kadar glukosa darah pada tikus putih strain wistar model diabetikum. Persamaan tersebut dapat digunakan, hal ini dikarenakan sig anova regresi $=0,000$ $<\alpha=0,01$. Koefisien determinasi $\mathrm{R}^{2}=0,814$, berarti penurunan kadar glukosa darah puasa pada tikus putih strain wistar ditentukan oleh 81,4\% pemberian dosis ekstrak biji anggur merah (Vitis vinifera).

Penelitian ini merupakan penelitian true experiment dengan Pre Post Test Control Group Design untuk membuktikan pengaruh ekstrak biji anggur merah (Vitis vinifera) terhadap penurunan kadar glukosa darah tikus putih strain wistar yang diinduksi Alloxan. Penelitian ini dilakukan selama 1 bulan. Tikus diadaptasikan dengan lingkungan 
sekitar selama 7 hari kemudian dilakukan injeksi Alloxan pada kelompok I, II dan III selama 7 hari. Pada tikus kelompok II dan III dilakukan pemberian ekstrak biji anggur merah (28 hari) dengan dosis yang telah ditentukan pada hari ke 8 setelah pemberian Alloxan sedangkan pada kelompok I dibiarkan selama 28 hari. Hasil penelitian menunjukkan bahwa kelompok I atau kontrol positif memiliki rerata kadar glukosa darah paling tinggi yaitu $97,615 \mathrm{mg} / \mathrm{dl}$ pada saat puasa dan 216,784 2 jam PP, karena efek alloxan menyebabkan tikus putih strain wistar dalam keadaaan hiperglikemik serta tidak adanya perlakuan pemberian ekstrak biji anggur merah. Keadaan hiperglikemik dapat dijelaskan melalui teori yang menyatakan bahwa alloxan menyebabkan kerusakan sel $\beta$ pankreas. Substansi diabetogenik ini secara selektif bekerja pada sel $\beta$ pankreas yang bertanggung jawab untuk memproduksi insulin (Szkudelski, 2008). Alloxan dalam darah berikatan dengan GLUT-2 (pengangkut glukosa) yang memfasilitasi masuknya Alloxan ke dalam sitoplasma sel $\beta$ pankreas. Di dalam sel $\beta$, Alloxan menimbulkan depolarisasi berlebih pada mitokondria sebagai akibat pemasukan ion $\mathrm{Ca}^{2+}$ yang diikuti dengan penggunaan energi berlebih sehingga terjadi kekurangan energi dalam sel. Dua mekanisme ini mengakibatkan kerusakan baik dalam jumlah sel maupun massa sel pankreas sehingga terjadi penurunan pelepasan insulin yang mengakibatkan terjadinya hiperglikemi (Lenzen, 2007).

Pada kelompok II, setelah pemberian ekstrak biji anggur merah dengan dosis 0,093 gr/200 gr BB/hari, didapatkan penurunan kadar glukosa pada tikus putih dimana kadar glukosa darahnya lebih rendah dari kelompok kontrol positif. Pada kelompok III, setelah pemberian ekstrak biji anggur merah dengan dosis 0,187 gr/200 gr BB/hari, didapatkan kadar glukosa terendah dibanding kelompok perlakuan lain yaitu $65,724 \mathrm{mg} / \mathrm{dl}$ untuk gula darah puasa dan 149,558 mg/dl untuk gula darah 2 jam PP. Penurunan kadar glukosa darah dapat dijelaskan melalui dua mekanisme utama yaitu secara intra pankreatik dan ekstra pankreatik (Whoter, 2001). Mekanisme intra pankreatik bekerja dengan cara memperbaiki sel pankreas yang rusak dan melindungi sel dari kerusakan serta merangsang pelepasan insulin ( $\mathrm{Li}$ MX, 2001). Mekanisme ekstra pankreatik dapat berlangsung melalui berbagai mekanisme. Alkaloid menurunkan glukosa darah dengan cara menghambat absorbsi glukosa di usus, meningkatkan transportasi glukosa di dalam darah, merangsang sintesis glikogen dan menghambat sistesis glukosa dengan menghambat enzim glukosa 6-fosfatase, fruktosa 1,8-bifosfatase serta meningkatkan oksidasi glukosa melalui glukosa 6-fosfat dehidrogenase. Glukosa 6-fosfatase dan fruktosa 1,6-bifosfatase merupakan enzim yang berperan dalam glukoneogenesis. Penghambatan pada kedua enzim ini akan menurunkan pembentukan glukosa dari substrat lain selain karbohidrat (Whoter, 2001).

Hasil analisis data pada uji one way ANOVA menunjukkan bahwa nilai sig $=0,000<\alpha=0,01$, hal ini berarti terdapat pengaruh yang bermakna antara pemberian ekstrak biji anggur merah terhadap penurunan kadar glukosa darah pada tikus putih strain wistar. Hasil uji Tukey 1\% menunjukkan bahwa kelompok I, II dan III memiliki notasi berbeda yang berarti terdapat perbedaan nyata antara saat pengukuran glukosa darah puasa maupun glukosa darah 2 jam PP.

Kandungan ekstrak biji anggur merah yang dapat digunakan untuk menurunkan glukosa darah adalah flavonoid, OPC dan catechin (Baghci, 1998). OPC merupakan tipe paling umum dari flavonoid yang banyak ditemukan pada makanan yang dikonsumsi manusia (Santos-Buelga, 2000), dimana OPC dapat berperan sebagai antioksidan melalui beberapa mekanisme yaitu scavenging free radicals, chealation of transition metals, serta inbibitor enzim (Aron, 2007). Mekanisme pertama sebagai scavenging free radicals. OPC memiliki konfigurasi elektron yang dapat mempermudah pengeluaran beberapa elektron untuk spesies radikal bebas seperti anion superoksida, hidroksida dan nitric oxide. Terjadinya pengeluaran elektron bebas dari proses reactive oxygen spesies akan langsung ditangkap oleh oligomer proanthocyanidin complex. Sebagai scavenging free radicals, oligomer proanthocyanidin complex bersifat lebih aman dan memiliki senyawa yang lebih stabil dibandingkan dengan initial radical spesies yang lain (Havsteen, Kitao et al, 2006). Mekanisme kedua sebagai chealation of transition metal, terdapat dua reaksi yang berperan dalam proses ini yaitu reaksi Fenton dan reaksi Haber-Weiss (Cos, De Bruyne et al, 2004). Pada reaksi Fenton, $\mathrm{Fe}^{2+}$ mengkatalis terbentuknya radikal hidroksida. Kemampuan dari oligomer proanthocyanidin complex untuk mengikat divalent transition metals secara efektif mengurangi konsentrasi dari kation dan perluasan dari aktivitas oksidasi (Beecher 2004).

Flavonoid merupakan antioksidan kuat yang berpengaruh kepada status redoks intraseluler (Coskun, 2005). Kemampuan Flavonoid sebagai antioksidan mampu menurunkan stress oksidatif. Hal ini dapat menimbulkan efek protektif terhadap sel beta pankreas dan meningkatkan sensitivitas insulin (Kaneto et al, 1999). Mekanisme ini melalui dua jalur. Jalur pertama sebagai peredam radikal bebas secara langsung dengan menyumbangkan atom hidrogennya. Flavonoid akan teroksidasi oleh radikal bebas menjadi senyawa yang lebih stabil. Jalur kedua melalui chelating ion logam (Nijveldt et al, 2001). Flavonoid memiliki mekanisme dalam penghambatan fosfodiesterase sehingga kadar cAMP dalam sel $\beta$ pankreas meninggi. Hal ini akan merangsang sekresi insulin melalui jalur $\mathrm{Ca}^{2+}$ (Ohno et al, 1993). Peningkatan kadar cAMP ini akan menyebabkan penutupan kanal $\mathrm{K}+\mathrm{ATP}$ dalam membran plasma sel beta. Keadaan ini mengakibatkan terjadinya depolarisasi membrane dan membukanya saluran $\mathrm{Ca}^{2+}$ tergantung- voltase sehingga mempercepat masuknya ion $\mathrm{Ca}^{2+}$ ke dalam sel. Peningkatan ion $\mathrm{Ca}^{2+}$ dalam sitoplasma sel beta ini akan menyebabkan sekresi insulin oleh sel $\beta$ pankreas (Sato et al, 1999; Yamada et al, 2002). Polifenol dan catechin telah ditemukan efisien sebagai penangkal radikal bebas (Rice-Evans, 1999). Kemampuan dari senyawa tersebut untuk bertindak sebagai penangkal radikal bebas adalah terkait dengan potensi pengurangan satu-elektron, ukuran reaktivitas antioksidan adalah sebagai hidrogen atau donor elektron (Halliwell, 1999).

Dari tabel uji korelasi antara perlakuan dan penurunan kadar glukosa darah pada tikus putih menunjukkan bahwa nilai sig $=0,000$ yang berarti kurang dari $\alpha(0,01)$, sehingga 
dapat disimpulkan terdapat korelasi yang bermakna antara pemberian ekstrak biji anggur merah dan penurunan glukosa darah. Korelasi yang terjadi pada penelitian menunjukkan korelasi yang berbanding terbalik bermakna yang berarti bahwa semakin tinggi dosis ekstrak biji anggur merah menyebabkan semakin besar penurunan glukosa darah puasa tikus putih strain wistar diabetes pada akhir perlakuan. Hal ini ditunjukkan dengan nilai pearson correlation $=$ 0,902 untuk pengukuran glukosa darah puasa dan pearson correlation $=0,962$ untuk pengukuran glukosa darah 2 jam post pandrial. Maka dosis paling efektif pada penelitian ini adalah dosis sebesar 0,187 gr/200 gr BB/hari pada kelompok III. Hasil uji regresi menunjukkan penurunan kadar glukosa darah puasa pada tikus putih strain wistar ditentukan oleh $81,4 \%$ pemberian dosis ekstrak biji anggur merah (Vitis vinifera) pada pengukuran glukosa darah puasa dan 92,5\% pada pengukuran glukosa darah 2 jam post pandrial. Dari berbagai fakta yang ditemukan pada penelitian ini dan melalui kajian statistika, maka hipotesis tentang pemberian ekstrak biji anggur merah terhadap penurunan glukosa darah tikus putih strain wistar yang diinduksi alloxan terbukti, namun masih memerlukan penelitian lebih lanjut untuk mengetahui mekanisme pasti ekstrak biji anggur merah dalam menurunkan glukosa darah.

\section{SIMPULAN}

Kesimpulan penelitian ini adalah Pemberian Ekstrak Biji Anggur Merah (Vitis vinifera) dapat menurunkan kadar glukosa darah tikus putih strain wistar model diabetikum. Pemberian Ekstrak Biji Anggur Merah (Vitis vinifera) dengan dosis yang berbeda dapat menurunkan kadar glukosa darah tikus putih strain wistar model diabetikum dengan perbedaan yang signifikan. Dosis yang paling efektif dalam penelitian ini adalah $0,187 \mathrm{gr} / 200 \mathrm{gr} \mathrm{BB} /$ hari.

\section{DAFTAR PUSTAKA}

Adam JMF, 2000, Klasifikasi dan Kriteria Diagnosis Diabetes Melitus yang Baru, CDK :127.

Al-Awwadi NAJ, Poucheret P, Cassanas G, et al, 2004, Antidiabetic activity of red wine polyphenolic extract, ethanol, or both in streptozotocin-treated rats, J Agric Food Chem, Vol.52, pp.1008-1016.

American Society of Health System Pharmacist, 2000, Herbal Companion To AHFS, Bethesda United States of America, pp.55-56. Published.

Armitage D, 2006, Rattus Norvegicus, Musseum of zoology University of Micchigan, viewed 12 February 2011,< http://animaldiversity. ummz.edu>.

Aron, Patricia M, 2007, Composition of Flavonoid Phenolic Polymers Isolated From Red Wine During Maceration and Significance of Flavan-3-ols in Foods Pertaining to Biological Activity, Thesis for the degree of Masters of Science in Food Science and Technology, Oregon State University, USA.

Arora Poonam, 2010, Bio-Functional of Grape Seeds-A Review, International Journal of Phytomedicine, 2, pp. $177-$ 185.

Bagchi D, Garg A, Krohn RL, et al, 1998, Protective effects of grape seed proanthocyanidins and selected antioxidants against TPA-induced hepatic in mice. Genetic Pharmacol, 30, pp. 771-776. Beecher, Gary R, 2004, Proanthocyanidins: Biological Activities Associated with Human Health, Pharmaceutical Biology Volume 42 Supplement, USA, pp. 2-20.

Casarett Doull's, 2001, Toxicology : The Basic Science of Poisons, Sixth Edition, Mc Graw-Hill, University of Kansas, USA.

Chauhan Alka, Meera Agarwal, Sonalika Kushwaha, et al, 2008, Antifertility studies of Aegle marmelos Corr., an Indian medicinal plant on male albino rats, Egyptian Journal of Biology, 10, pp. 28-33.

Chevallier Andrew, 1996, The Encyclopedia Medicinal Plants, Dorling Kindersley, Henrietta London , 9, pp.281.

Chris Kilham, 2009, OPC: The Miracle Antioxidant. University of Maryland, Medical Centre. ADAM Press.

Cos, P., T. De Bruyne, 2004, Proanthocyanidins in health care: Current and new trends, Current Medical Chemistry 11(10) pp. 1345-1359.

Coskun O, Kanter M, Korkmaz A, et al, 2005, Quercetin, a flavonoid antioxidant, prevents and protects streptozotocininduced oxidative stress and b-cell damage in rat pancreas. Pharmacol Res 51 pp.117-23. Dalimartha, Setiawan, 1999, Atlas Tumbuhan Obat Indonesia, Jilid 1, Puspa Swara, Depok.

Dalimartha S, 2007, Ramuan Tradisional Untuk Pengobatan Diabetes Melitus, Cetakan 12, Penebar Swadaya, Jakarta.

Ehrlich Steven, 2011, Grape seed,University of Maryland Medical Centre, ADAM press. Viewed February,2011. <http://www.umm.edu/altmed/articles/grape-seed000254.htm> Furnawanthi, 2002, Khasiat dan Manfaat Lidab Buaya, Cetakan 1, Agro Media Pustaka, Jakarta.

Ghoshal MN, 1978, Fundamental of Experimental Pharmacology, Scientific Book Agency, Calcuta. pp. 1-5.

Guthrie DW, Guthrie RA, 2003, The Diabetes Source Book, Mc Graw Hills Company, New York, pp.13-14.

Guyton \& Hall, 2008, Fisiologi Manusia : Insulin, Glukagon, dan Diabetes Melitus, EGC, Jakarta.

Halliwell B. and Gutteridge J. M. C., 1999, Free Radicals in Biology and Medicine, $3^{\text {rd }}$ ed., Oxford University Press : New York.

Hassan HMM, Nahla, 2010, In vitro Antioxidant and Free Radical Scavenging Activities of Red Grape Seed Extracts, Global Journal of Biotechnology \& Biochemistry Egypt, pp. 106-115.

Havsteen, B. H, 2002, The biochemsitry and medical significance of the Flavonoids, Pharmacol and Therapeutics 96 pp.67202.

Isselbacher KJ, Braundwald E, Wilson JD, et.al, 2000, Harrison:Prinsip-Prinsip

Ilmu Penyakit Dalam, Vol.5, EGC, Jakarta.

Kaneto Hideaki, Naoto Katakami, Miyoko Saito, et al, 2009, Combined effect of oxidative stress-related gene polymorphisms on the progression of carotid atherosclerosis in Japanese type 2 diabetes Atherosclerosis, Diabetes Research and Clinical Practice,Volume 207, Issue1, pp. 29-31.

Katiyar SK, 2008, Grape seed proanthocyanidines and skin cancer prevention: inbibition of oxidative stress and protection of immune system, Mol Nutr Food Res, Vol.52, pp.71-76. 
Kelimeler A, 2003, The Effect of Alloxan Diabetes in Rats on Gingival Tissue, Viewed Desember 2010, <http:// www.gudisdergi.gazi.edu.tr/20-2/s-35.doc $>$

Kemper Kathi J, 1999, Oligomeric Proanthocyanidin Complex (OPCs) - Pycnogenols, Pine Bark Extract, Grape Seed Extract, The Centre for Holistic Pediatric Education and Research. Viewed $2011<$ http://www.mcp.edu/ herbal/default.htm>

Kitao, S., M. Teramoto, 2006, Stabilizing effect of grape seed extract on ascorbic acid, Food Science Technology Res 12(1) pp.15-20.

Kumalaningsih Sri, 2007, Antioksidan Alami Penangkal Radikal Bebas, Trubus

Swadaya, Depok.

Kusumawati D, 2004, Bersahabat dengan hewan coba, Fakultas Kedokteran Hewan Universitas Airlangga, Gajah Mada University Press, Surabaya.

Lampe JW, 1999, Health Effects of Vegetables and Fruit: Assesing Mechanism of Action in Human Experimental Studies, The American Journal of Clinical Nutrition, pp. 475-490.

Laurance, Bacharach, 1964, Evaluation of Drug Activities: Pharmacometrics, Academic Press, London and New York, pp. 135-179.

Lenzen S, 2007, The Mechanism of Alloxan and Streptozotoccin Induced Diabetes, Institute of Clinical Biochemistry, Hannover Medical School, Germany. <http:// mhhannover. de/k/inische_ biochemistry. html>

Li MX, Akira Kazuhito Y, Takao K, et al, 2001, Pancreatic Islet Regeneration by Ephedrine in Mice with Streptozocin Induced Diabetes, Viewed 2010, <http:// www.findarticles.com / p / / mi_mOHKP / is_2001_Summer-Fall/ai_81596700>

Liers, Hank, 1993, On Oligomeric Proanthocyanidins (OPC), Health Products Distributors.

Maulana, M, 2008, Mengenal Diabetes: Panduan Praktis Menangani Penyakit Kencing Manis., Katahati , Yogyakarta.

Monorahardjo Hermani, 2005, Tanaman Berkhasiat Antioksidan, Penebar Swadaya, Jakarta.

Mulder H, Samuel GM, Christer B, et al, 2005, Islet Amyloid Polypeptide

(Amylin)-Deficient Nice Develop a More Severe Foam of AloxxanInduced

Diabetes, Journal of Biomedicine and Biotechnology.

Murray RK, Granner DK, Mayes PA, et al, 2003, Harper Biochemistry. 25 ${ }^{\text {th }}$ Edition, diterjemahkan : Hartono A dalam Biokimia Harper EGC, Jakarta, pp. 581-597.

Nicholas JS, 1971, Experimental Methode and Rat Embryos: The Rat in

Laboratory Investigation, Hafner Publishing Company, New York, pp.51-54.

Nijveldt,R.J, F, van Nood, P.G,Boelen, 2001, Flavonoids : a review of probable mechanism of action and potential applications, Jurnal Clinical Nutrition74 pp.418-425, Amsterdam.

Nugroho Agung Endro, 2006, Hewan Percobaan Diabetes Mellitus : Patologi Dan Mekanisme Aksi Diabetogenik, Biodiversitas, Laboratorium Farmakologi Dan Toksikologi, Bagian Farmakologi Dan Farmasi Klinik, Fakultas Farmasi Universitas Gadjah Mada, Yogyakarta. Published
Ohno T, 1993, Quercetin potentiates TNF-induced antiviral activity, Antiviral Res, Vol.22, pp.327-331.

PERKENI, 2006, Konsensus Pengelolaan dan Pencegahan Diabetes Melitus Tipe 2 di Indonesia, Jakarta.

Pernesz G , 2008, New Resistant Table Grape Cultivars Bred in Hungary, International Society for Horticultural Science.

Purnamasari Dyah, 2009, Diagnosis dan Klasifikasi Diabetes Melitus, dalam Buku Ajar Ilmu Penyakit Dalam Jilid III Edisi V, Pusat Penerbitan Departemen Ilmu Penyakit Dalam Fakultas Kedokteran Universitas Indonesia, Jakarta, pp.1880-1883.

Power, Alvin, 2008, Diabetes Mellitus, Harrison's: Principle of Internal

Medicine, $17^{\text {th }}$ Edition, McGraw-Hill Companies, USA.

Rice-Evans C, 1999, Implications of the mechanisms of action of tea polyphenols as antioxidants in vitro for chemoprevention in humans, Proc. Soc. Exp. Biol. Med ; 220 pp.262-266.

Rohdiana Dadan, 2009, Teh Ini Menyehatkan, Alfabeta, Bandung.

Rukmana R, 1998, Budidaya dan Penangan Pasca Panen Anggur, Kanisius, Yogyakarta, pp. 17-23; 27-28.

sacks D.B, 2001, Carbohydrates in Tietr. Fundamentalis of Clinical Chemistry Eds Burtis C. A. A. Swood e. R., 5th Edition, Saunders Company, USA.

Sato, 1999, Mechanism of antioxidant action of pueraria glycoside (PG)-l (an isoflavonoid) and maniferin (a xanthonoid), Chem Pharm Bull, Vol.40, pp.721-724.

Sauri Herly, 1991, Budidaya Anggur, Usaha Nasional, Surabaya. Shi, John, 2003, Polyphenolics in Grape Seeds-Biochemistry and Functionality, University of Guelph Ontario, Canada, Journal of Medicinal Food, Vol.6, pp.291-299.

Shimizu M, Kobayashi Y, Suzuki M, et al, 2000, Regulation of intestinal glucose transport by tea catechins. Biofactors, Vol.13, pp.61-65.

Santos-Buelga, C. and A. Scalbert, 2000, Review: Proanthocyanidins and Tannin- Like Compounds - Nature, Occurence, Dietary Intake and Effects on Nutrition and Health, J Sci Food Agri chapter.80 pp.1094-1117.

Studiawan, Santosa MH, 2005, Uji Aktivitas Penurun Kadar Glukosa Darah Ekstrak. Daun Eugenia polyantha pada Mencit yang Dïnduksi Aloksan, Bagian Ilmu Bahan Alam, Fakultas Farmasi, Universitas Airlangga, Surabaya. Published

Subehi, Mohammad, 2008, Anggur, Trubus, Trubus Swadaya, Depok. Sudjari, 1996, Tikus Wistar Sebagai Hewan Coba Untuk Penelitian Dengan

Toksoid Tetanus, Majalah Kedokteran Unibraw, Malang, Vol.XII.

Suharmiati, 2003, Pengertian Bioaktivitas Antidiabetes Militus Tumbuban Obat, Viewed Desember 2010, <http:// www.sigma-7/Cermin Dunia Kedokteran.com>.

Suhartono, Eko, 2007, Kapita Selekta Biokomia-Stres Oksidatif : Dasar \& Penyakit, Pustaka Banua, Banjarmasin.

Sunarjono, Hendro, 2007, Berkebun 21 Jenis Tanaman Buah, Penebar Swadaya, Jakarta.

Supranto J, 2007, Teknik Sampling Survey \& Eksperimen, Rineka Cipta, Jakarta, pp.217.

Suyono Slamet, 2009, Diabetes Melitus di Indonesia, dalam Buku Ajar Ilmu Penyakit Dalam Jilid III Edisi V, Pusat Penerbitan Departemen Ilmu Penyakit Dalam Fakultas Kedokteran Universitas Indonesia, Jakarta, pp.1874-1875. 
Szkudelski T, 2008, The mechanism of alloxan and streptozotocin in action in $B$ cells of the rat pancreas, <www.ncbi. nlm.nih.gov/pubmed/ 11829314>Thomas L, 1998, Clinical Laboratory Diagnositics, $1^{\text {st }}$ Edition, The Books Veriagsgeselischaft, Frankfurt.

Whorter Mc LS, 2001, Biologycal Complementary Therapies : A Focus on Botanical Products in Diabetes, viewed Desember 2010, <http://spectrum.diabetesjournals.org/cgi/content/full/14/4/199>.

Winarsi, Hery, 2007, Antioksidan Alami dan Radikal Bebas, Kanisius, Yogyakarta, pp.80.

Wirakusumah E.S, 1999, Buab dan Sayuran untuk terapi, Cetakan 5, Penebar Swadaya, Jakarta, pp.43-44.

Wiriyanta, Bernard T, Wahyu, 2008, Membuabkan Anggur di Dalam Pot dan Pekarangan, Agro Media Pustaka, Jakarta.

Wiyono P, Ignatia, 2004, Glimiperide: Generasi Baru Sulfonilurea, RS.Sardjito Penyakit Dalam, Yogyakarta, Published.

Youngson Robert, 2005, Antioksidan : Manfaat Vitamin C \& E bagi Kesehatan, Arcan, Jakarta, pp.113. 